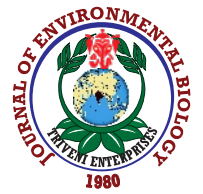

\title{
Elucidation of induced host plant resistance to white backed plant hopper (WBPH) in response to zinc application in rice
}

\author{
S. Tripathy', L.K. Rath ${ }^{1}$ and S.K. Tripathy ${ }^{2 *}$ \\ 'Department of Entomology, College of Agriculture, OUAT, Bhubaneswar-751 003, India \\ ${ }^{2}$ Department of Agricultural Biotechnology, College of Agriculture (OUAT), Bhubaneswar-751 003, India \\ *Corresponding Author Email : swapankumartripathy@gmail.com
}

\begin{tabular}{lll}
\hline Received: 08.02.2020 Accepted:07.08.2020 & Revised: 29.06 .2020 & Act
\end{tabular}

\begin{abstract}
Aim: The experiment was aimed to study the effects of various $Z n$ formulations towards induced host plant resistance to WBPH in rice.

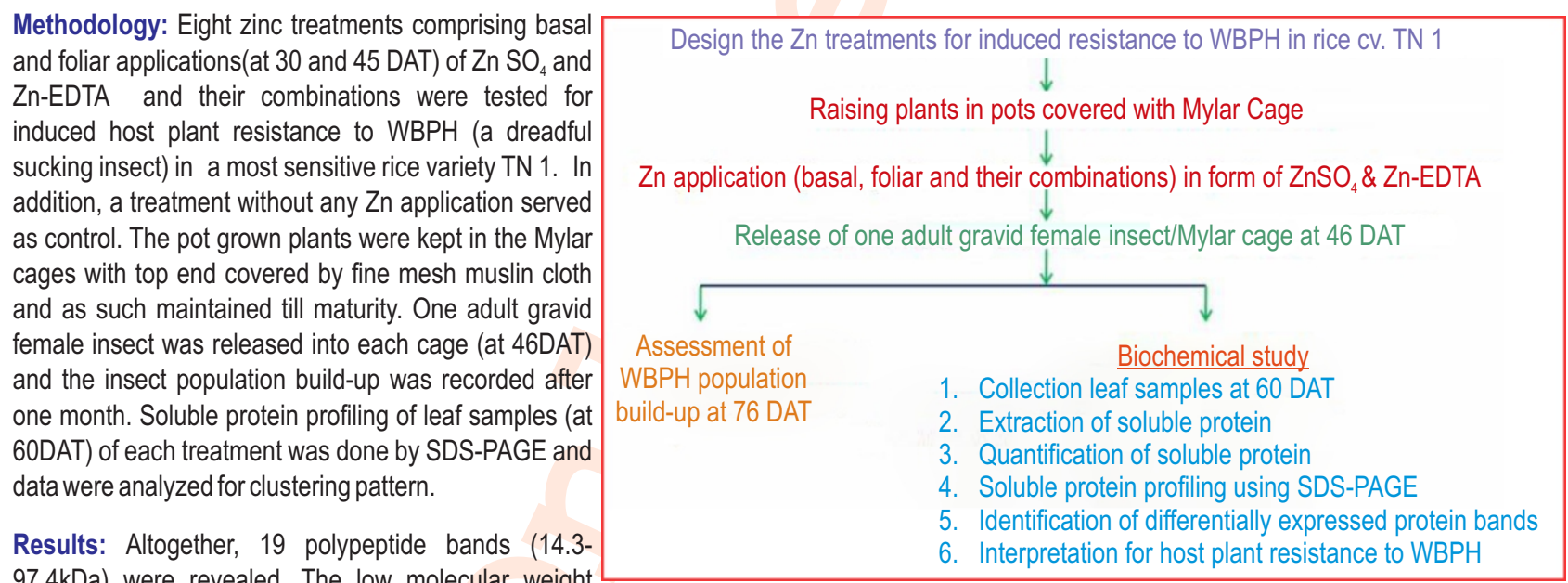
$97.4 \mathrm{kDa}$ ) were revealed. The low molecular weight proteins (14.3-25.1 kDa) were clearly absent in the control. $\mathrm{T}_{6}(\mathrm{Zn}$ EDTA at basal and foliar) recorded least WBPH build-up and elicited highest number (15) of polypeptide bands including five new bands at 66.0, 37.0, 23.6, 15.8 and 14.3 kDa. Further, 66.0kDa, 37.0 kDa and 14.3 kDa polypeptide bands were commonly shared by $\mathrm{T}_{6}, \mathrm{~T}_{7}\left(\mathrm{ZnSO}_{4}\right.$ basal+ EDTAfoliar) and $\mathrm{T}_{8}\left(\mathrm{Zn}\right.$ EDTA basal $\left.+\mathrm{ZnSO}_{4}\right)$ that recorded lower WBPH population and grouped together as compared to rest of the treatments and control. However, $23.6 \mathrm{kDa}$ polypeptide band induced only in $T_{6}$ and $T_{7}$ seems to have greater role in manifestation of induced defence mechanism against WBPH in rice.
\end{abstract}

Interpretation: The differentially expressed proteins (as compared to control) revealed in response to $\mathrm{Zn}$ application may be considered as biochemical basis of induced resistance for the pest in rice.

Key words: Induced resistance, Soluble protein profiling, White backed plant hopper, Zinc

How to cite : Tripathy, S., L.K. Rath and S.K. Tripathy: Elucidation of induced host plant resistance to white backed plant hopper (WBPH) in response to zinc application in rice. J. Environ. Biol., 42, 154-161 (2021). 


\section{Introduction}

Rice (Oryza sativa L.) is grown extensively in different parts of the world and one of the most important staple food crops of India and Odisha as well. Pests pose threats to rice production. Now-a-days, the situation is aggravated by climate change (Cabot et al., 2019) and indiscrimilate use of pesticides leading to pest resurgence and drastic toxicidal effect on beneficial bioagents (Satpathy et al., 2020). Micronutrient roles in plant defense are predominantly documented for $\mathrm{Mn}, \mathrm{Cu}, \mathrm{Fe}$, and $\mathrm{Zn}$ (Fones and Preston, 2012). Zinc serves as cofactor for more than 300 enzymes (Marreiro et al., 2017) and it is known to trigger plant growth and immunity system against biotic and abiotic stresses (Gupta et al., 2012) although a general model for Zn-related defense mechanism is not clear. $\mathrm{Zn}$ seems to have antagonistic role on insects by inhibiting a-amylase, which is an important digestive enzyme required for their survival and growth (Kaur et al., 2014). The $\mathrm{Zn}$ proteome is an important group of metalloprotein and it represents about $9 \%$ of the entire proteome in eukaryotes and 5-6\% in prokaryotes (Andreini et al., 2009). Insect infestation is reported to be related to the up-regulation of two zinc finger transcription factors in potato (Lawrence et al., 2014). Similarly, Chang et al. (2012) reported increased Zn-SOD (super oxide dismutase) activity due to insect infestation and it is negatively correlated with foliar damage (Khederi et al., 2018).

More than 100 species of insects have been reported to attack the rice crop (Krishanaiah et al., 2008). Among these white backed plant hopper (WBPH, Sogatella furcifera) is a major sucking pest of rice that causes nearly $35-95 \%$ yield loss under favourable condition (Sidhu, 1979; Sogawa et al., 2009). Hopper burn due to intensive sucking by WBPH together with its high fecundity and long-distance migration ability pose serious threat to rice cultivation (Zhai et al., 2013). Unfortunately, no truly resistant variety has been so far developed against this insect. However, application of various micronutrients can be an alternate non-conventional and eco-friendly sustainable plant protection approach to manage this pest through induction of host plant resistance. Zinc is one such micronutrient which can induce defence mechanism in rice against the sucking pest (Rath, 2004).

Out of four micronutrients (iron, zinc, copper and manganese), zinc is reported to be the most effective to induce antibiosis effect against BPH, WBPH and GLH (Rath, 2006) leading to reduced nymphal survival, growth index and population build up. Besides, the BPH incidence is reported to be inversely related with zinc $(r=-0.2690)$ and sulphur $(r=-0.2689)$ content of rice foliage (Dash et al., 2007) following application of $\mathrm{ZnSO}_{4}$ along with NPK fertilizers. Increase in expression of defense related protein after infestation (Edwards and Wratten, 1983) and induction of a specific protein $(53 \mathrm{kDa})$ due to leaf folder infestation in resistant and moderately resistant rice varieties have been reported by Das et al. (1999). Besides, Punithavalli et al. (2013) reported increased expression of a $38 \mathrm{kDa}$ protein due to leaf folder infestation, which served as a key for identification of leaf folder tolerant or resistant genotypes. Besides, elicitation of defense related protein in response to basal or foliar application of zinc in rice could be a biochemical basis of induced resistance to insects. Therefore, an experiment was designed to study the extent of induced resistance to WBPH in rice by application of zinc and to explore the role of $\mathrm{Zn}$-induced defense related protein for induced host plant resistance mechanism.

\section{Materials and Methods}

Zinc treatments: Twenty days old seedlings of a WBPH susceptible rice variety TN 1 were transplanted on $10 \mathrm{~kg}$ capacity earthen pots filled with puddled soil. Various $\mathrm{Zn}$ treatments taken were, $\mathrm{T}_{1}: \mathrm{ZnSO}_{4}$ basal $\left(25 \mathrm{~kg} \mathrm{ha}^{-1}\right), \mathrm{T}_{2}: \mathrm{Zn}$ EDTA basal ( $\left.40 \mathrm{~kg} \mathrm{ha}^{-1}\right)$, $\mathrm{T}_{3}: \mathrm{ZnSO}_{4}$ Foliar spray $(0.5 \%)$ (30 \& 45 days after transplanting (DAT)), $\mathrm{T}_{4}: \mathrm{Zn}$ EDTA foliar spray (0.8\%) (30 \& 45DAT), $\mathrm{T}_{5}: \mathrm{T}_{1}+\mathrm{T}_{3}$, $T_{6}: T_{2}+T_{4}, T_{7}: T_{1}+T_{4}, T_{8}: T_{2}+T_{3}$ and $T_{9}$ along with a treatment without any $Z n$ application to serve as control. After application of recommended fertilizer dose and basal $\mathrm{Zn}$ treatment in respective pots, they were covered by the Mylar cages of $45 \mathrm{~cm}$ height with top end covered by fine mesh muslin cloth. The plants were maintained as such under cage till maturity. At 30 and 45 DAT; foliar applications of Zn were imposed on the plants. All the experiments were done in green house of the Department of Entomology, College of Agriculture, Odisha University of Agriculture and Technology (OUAT), Bhubaneswar.

Assessment of WBPH population: At 46 DAT, 3-4 days old, one adult gravid female insect was released into each cage. After one month of release, the population of WBPH was counted, replication-wise as per Heinrichs et al. (1985).

Soluble protein extraction and quantification: As the WBPH population build-up attained highest at 60DAT in the control (without Zn application in cv. TN 1); leaf samples from different treated caged plants were collected at this stage for quantitative and qualitative analysis of protein and also to explore the presence of any new defence protein responsible for inducing host plant resistance. For the purpose, soluble protein was extracted from leaves using Tris extraction buffer $(20 \mathrm{mM}$ Tris$\mathrm{HCl}, \mathrm{pH} 7.5 ; 50 \mathrm{mM} \mathrm{MgCl}_{2}, 2 \%$ PVP, 1mM PMSF) followed by precipitation with $50 \% \mathrm{TCA}+1 \% \beta-\mathrm{ME}$; and solubilisation in sample buffer (9M Urea, 4\% CHAPS, 1\% DTT and 1mM PMSF, 2\% Bio-Lyte) @ 1mg dried protein powder $/ 0.1 \mathrm{ml}$ buffer at 4oC overnight. The total soluble protein of each sample was quantified by the method suggested by Lowry et al. (1951).

Soluble protein profiling and gel documentation: Total soluble protein profiling was carried out by Sodium Dodecyl SulphatePoly Acrylamide Gel Electrophoresis (SDS-PAGE) according to Lagrimini and Rothstein (1987). Reproducibility was confirmed by minimum of two repeats of each run of SDS-PAGE under similar electrophoretic conditions. After electrophoresis, gels were stained with $0.125 \% \mathrm{w} / \mathrm{v}$ coomassie brilliant Blue R 250, 50\% v/v methanol, and $10 \% \mathrm{v} / \mathrm{v}$ glacial acetic acid for four hours with intermittent shaking followed by destaining overnight in $50 \%$ methanol and 10\% glacial acetic acid; and finally, several 
washings with $5 \%$ methanol and $7 \%$ glacial acetic acid. Thereafter, the gels were placed on Gel Documentation System (Fire Reader-Uvtec, Cambridge, UK) for assessment of banding pattern and photographed. The presence and absence of polypeptide bands were scored as 1 and 0 respectively to determine variation among various zinc treatments. The relative mobility of each polypeptide band was calculated using software of the Gel doc system. The molecular weights of the dissociated polypeptides were determined by using molecular weight marker of protein standards which consisted six standard proteins of known molecular weight i.e. lysozyme $(14.3 \mathrm{kDa})$, soybean trypsin inhibitor(20.1 kDa), carbonic anhydrase $(29 \mathrm{kDa})$, ovalbumin $(43 \mathrm{kDa})$, bovine serum albumin $(66 \mathrm{kDa})$ and phosphorylase-b (97.4kDa). Differentially expressed unique polypeptide bands were noted to find relationship with WBPH tolerance.

Statistical analysis: The data sets for total soluble protein $(\mathrm{mg} / \mathrm{g})$ and WBPH population build-up per plant were subjected to Duncan's multiple range test (Duncan,1955). Means superscripted by same letter were considered not significantly different at $P \leq 0.05$. The binary data set ( $1 / 0$ score) of soluble protein profile was subjected to estimation of Jaccard's similarity co- efficient values and construction of dendrogram (clustering pattern) using the procedures of Jaccard (1908), and Sokal and Michener (1958) respectively.

\section{Results and Discussion}

Preference/non-preference of a variety by the insect is greatly assessed by the population load of the insect on the variety within a stipulated time. Higher degree of suitability of the plant variety by insect(s) results typical susceptibility (more insect population) reaction while, in-build resistance mechanism(s) in the host plant leads to unsuitability by same insect. A perusal of data depicted in Table 1 revealed that the population build-up of WBPH on rice plants subjected to various application of $\mathrm{Zn}$ treatments varied significantly among the treatments after a constant time interval. In the present study, population build up of WBPH was found to be highest in the control treatment (79.2 per hill) which was significantly very high than all other zinc treatments. The lowest population of WBPH (31.40) was visualized in $T_{6}$ which was statistically different from all other treatments. Even the treatment $\mathrm{T}_{6}$ revealed nearly $60 \%$ less population when compared with control. Closely following T6, the treatment $T_{7}$ and $T_{8}$ supported 38.20 and 41.60 insects respectively as compared to the control. There was variation between $T_{1}$ and $T_{2}$ but $T_{2}$ did not differ from $T_{3}$ and $T_{4}$ treatments. Earlier workers (Rath, 2004; Dash and Mishra, 2009) have also witnessed low population build-up of WBPH in rice being subjected to zinc application. In this context, increased silica and zinc content in plants is reported to offer induced resistance to stem borer in paddy (Chandramani et al., 2010; Dash et al., 2011, Madhuri et al., 2017).

Total soluble protein content of leaves of rice cv. TN 1 was estimated to be $8.76 \mathrm{mg} \mathrm{g}^{-1}$ in the untreated control, but it was increased in all zinc treatments except $T_{1}$ which was at par with control. Further, it is worth to note that protein content (Table 1) was highest in $T_{6}\left(10.51 \mathrm{mg} \mathrm{g}^{-1}\right)$ and it was at par with $\mathrm{T}_{8}(10.43 \mathrm{mg}$ $\left.\mathrm{g}^{-1}\right)$ and $\mathrm{T}_{7}\left(9.93 \mathrm{mg} \mathrm{g}^{-1}\right)$. Interestingly, these treatments revealed less pest population build-up of WBPH. Similarly, Hori and Atalay (1980) observed increase in soluble protein content up to the 3rd day after infestation by Lygus disponsi bug in cabbage. The initial increase in protein content may be due to over expression of defense related proteins. However, exact role of $\mathrm{Zn}$ application in variation of soluble protein content is not clear in this study. In contrast, Raghumoorthy and Gunathilagaraj (1988) reported decrease in total seed proteins in the resistant rice varieties $\mathrm{CO} 1$, $\mathrm{CO} 24$ and $\mathrm{CO} 32$ to angoumois grain moth.

Similar results have also been reported on corn leaves of resistant and susceptible varieties by Beck et al. (1983). A slight decrease in the total protein content was invariably revealed in

Table 1: Impact of zinc application on total soluble protein content and population build-up of white backed plant hopper (WBPH) in rice

\begin{tabular}{|c|c|c|}
\hline Treatments & $\begin{array}{l}\text { Total soluble } \\
\text { protein }\left(\mathrm{mg} \mathrm{g}^{-1}\right)\end{array}$ & $\begin{array}{l}\text { Population } \\
\text { Build-up/plant* }\end{array}$ \\
\hline $\mathrm{T}_{1}: \mathrm{ZnSO}_{4}$ basal $\left(25 \mathrm{~kg} \mathrm{ha}^{-1}\right)$ & $8.89^{c}$ & $53.60^{b}$ \\
\hline $\mathrm{T}_{2}:$ Zn EDTA basal $\left(40 \mathrm{~kg} \mathrm{ha}^{-1}\right)$ & $9.15^{\mathrm{bc}}$ & $51.20^{\mathrm{bc}}$ \\
\hline $\mathrm{T}_{3}:$ ZnSO4 foliar spray @ 0.5\% twice at 30 and 45 DAT & $9.31^{\mathrm{bc}}$ & $49.80^{\mathrm{bc}}$ \\
\hline $\mathrm{T}_{4}:$ Zn EDTA Foliar spray @ 0.8\% twice at 30 and 45 DAT & $9.62^{\mathrm{abc}}$ & $49.00^{\text {cd }}$ \\
\hline $\mathrm{T}_{5}: \mathrm{ZnSO} 4$ basal $\left(25 \mathrm{~kg} \mathrm{ha}^{-1}\right)+\mathrm{ZnSO}_{4}$ foliar spray @ 0.5\% twice at 30 and 45 DAT & $9.67^{\mathrm{abc}}$ & $45.20^{\text {de }}$ \\
\hline $\mathrm{T}_{6}:$ Zn EDTA basal $\left(40 \mathrm{~kg} \mathrm{ha}^{-1}\right)+\mathrm{Zn}$ EDTA Foliar spray@ 0.8\% twice at 30 and 45 DAT & $10.51^{\mathrm{a}}$ & $31.40^{\circ}$ \\
\hline $\mathrm{T}_{7}: \mathrm{ZnSO} 4$ basal $\left(25 \mathrm{~kg} \mathrm{ha}^{-1}\right)+\mathrm{Zn}$ EDTA Foliar spray @ $0.8 \%$ twice at 30 and 45 DAT & $9.93^{\mathrm{ab}}$ & $38.20^{\dagger}$ \\
\hline $\mathrm{T}_{8}: \mathrm{Zn}$ EDTA basal $\left(40 \mathrm{~kg} \mathrm{ha}^{-1}\right)+\mathrm{ZnSO}_{4}$ foliar spray @ $0.5 \%$ twice at 30 and 45 DAT & $10.43^{\mathrm{a}}$ & $41.60^{\mathrm{ef}}$ \\
\hline $\mathrm{T}_{9}$ : Control & $8.76^{c}$ & $79.20^{\mathrm{a}}$ \\
\hline $\mathrm{SE}_{(\mathrm{m})} \pm$ & 0.327 & 1.406 \\
\hline C.D. $(0.05)$ & 0.97 & 4.03 \\
\hline
\end{tabular}

${ }^{*}$ Mean of five replications. Means followed by same letter are not significantly different from each other 
Table 2: SDS-PAGE polypeptide banding pattern of total soluble protein samples extracted from rice leaves after application of zinc

\begin{tabular}{|c|c|c|c|c|c|c|c|c|c|c|c|}
\hline $\begin{array}{l}\text { Poly-peptide } \\
\text { band }\end{array}$ & $\begin{array}{l}\text { Mol. Wt. } \\
\text { (kDa) }\end{array}$ & $\begin{array}{l}\mathrm{T}_{1} \mathrm{ZnSO}_{4} \\
\text { basal } \\
\left(25 \mathrm{~kg} \mathrm{ha}^{-1}\right)\end{array}$ & $\begin{array}{l}\mathrm{T}_{2} \mathrm{Zn} \text { EDTA } \\
\text { basal } \\
\left(40 \mathrm{~kg} \mathrm{ha}^{-1}\right)\end{array}$ & $\begin{array}{l}\mathrm{T}_{3} \mathrm{ZnSO}_{4} \text { foliar } \\
\text { spray }(0.5 \%) \\
\text { (30 and } 45 \mathrm{DAT})\end{array}$ & $\begin{array}{l}\mathrm{T}_{4} \mathrm{Zn} \text { EDTA foliar } \\
\text { spray }(0.8 \%) \\
(30 \text { and } 45 \mathrm{DAT})\end{array}$ & $\begin{array}{l}T_{5} \\
\left(T_{1}+T_{3}\right)\end{array}$ & $\begin{array}{l}T_{6} \\
\left(T_{2}+T_{4}\right)\end{array}$ & $\begin{array}{l}\mathrm{T}_{7} \\
\left(\mathrm{~T}_{1}+\mathrm{T}_{4}\right)\end{array}$ & $\begin{array}{l}T_{8} \\
\left(T_{2}+T_{3}\right)\end{array}$ & $\begin{array}{l}\mathrm{T}_{9} \\
\text { (Control) }\end{array}$ & $\begin{array}{l}\text { Total } \\
\text { bands }\end{array}$ \\
\hline B1 & 97.4 & 1 & 1 & 1 & 1 & 1 & 1 & 1 & 1 & 1 & 9 \\
\hline B2 & 90.0 & 1 & 1 & 1 & 1 & 1 & 1 & 1 & 1 & 1 & 9 \\
\hline B3 & 85.5 & 0 & 1 & 1 & 1 & 1 & 1 & 1 & 1 & 1 & 8 \\
\hline B4 & 78.0 & 1 & 1 & 1 & 1 & 1 & 1 & 1 & 1 & 1 & 9 \\
\hline B5 & 72.2 & 1 & 1 & 1 & 1 & 1 & 1 & 0 & 1 & 1 & 8 \\
\hline B6 & 66.0 & 1 & 0 & 0 & 0 & 0 & 1 & 1 & 1 & 0 & 4 \\
\hline B7 & 56.8 & 0 & 1 & 1 & 1 & 1 & 1 & 1 & 1 & 1 & 8 \\
\hline B8 & 40.2 & 1 & 1 & 1 & 1 & 1 & 1 & 1 & 1 & 1 & 9 \\
\hline B9 & 37.0 & 1 & 0 & 0 & 0 & 0 & 1 & 1 & 1 & 0 & 4 \\
\hline B10 & 35.0 & 0 & 1 & 1 & 1 & 1 & 1 & 1 & 1 & 1 & 8 \\
\hline B11 & 33.0 & 1 & 0 & 0 & 0 & 0 & 0 & 0 & 0 & 0 & 1 \\
\hline B12 & 29.0 & 0 & 1 & 1 & 1 & 1 & 1 & 1 & 1 & 1 & 8 \\
\hline B13 & 27.3 & 1 & 1 & 1 & 1 & 1 & 1 & 1 & 1 & 1 & 9 \\
\hline B14 & 25.1 & 1 & 0 & 0 & 0 & 0 & 0 & 0 & 0 & 0 & 1 \\
\hline B15 & 23.6 & 0 & 0 & 0 & 0 & 0 & 1 & 1 & 0 & 0 & 2 \\
\hline B16 & 22.0 & 0 & 1 & 1 & 1 & 1 & 0 & 1 & 0 & 0 & 5 \\
\hline B17 & 20.1 & 0 & 1 & 1 & 0 & 0 & 0 & 0 & 0 & 0 & 2 \\
\hline B18 & 15.8 & 0 & 0 & 0 & 1 & 1 & 1 & 0 & 1 & 0 & 4 \\
\hline B19 & 14.3 & 0 & 1 & 1 & 1 & 1 & 1 & 1 & 1 & 0 & 7 \\
\hline Total bands & & 10 & 13 & 13 & 13 & 13 & 15 & 14 & 14 & 10 & 115 \\
\hline $\begin{array}{l}\text { WBPH popula } \\
\text { build- up }\end{array}$ & & 53.60 & 51.20 & 49.80 & 49.00 & 45.20 & 31.40 & 38.20 & 41.60 & 79.20 & \\
\hline
\end{tabular}

N.B.: Presence or absence of polypeptide bands marked by 1 and 0 respectively

Table 3: Similarity coefficient between zinc treatments for induced resistance to white backed plant hopper (WBPH) in rice

\begin{tabular}{|c|c|c|c|c|c|c|c|c|c|}
\hline Treatments & $\begin{array}{l}\mathrm{T}_{1} \mathrm{ZnSO}_{4} \\
\text { basal } \\
\left(25 \mathrm{~kg} \mathrm{ha}^{-1}\right)\end{array}$ & $\begin{array}{l}\mathrm{T}_{2} \mathrm{Zn} \text { EDTA } \\
\text { basal } \\
\left(40 \mathrm{~kg} \mathrm{ha}^{-1}\right)\end{array}$ & $\begin{array}{l}\mathrm{T}_{3} \mathrm{ZnSO}_{4} \text { foliar } \\
\text { spray }(0.5 \%) \\
(30 \text { and } 45 \\
\text { DAT) }\end{array}$ & $\begin{array}{l}T_{4} \text { Zn EDTA } \\
\text { foliar spray } \\
(0.8 \%)(30 \\
\text { and } 45 \text { DAT) }\end{array}$ & $T_{5} T_{1}+T_{3}$ & $\mathrm{~T}_{6} \mathrm{~T}_{2}+\mathrm{T}_{4}$ & $\mathrm{~T}_{7} \mathrm{~T}_{1+} \mathrm{T}_{4}$ & $\mathrm{~T}_{8} \mathrm{~T}_{2+} \mathrm{T}_{3}$ & $\begin{array}{l}\mathrm{T}_{9} \\
\text { Control }\end{array}$ \\
\hline $\begin{array}{l}\mathrm{T}_{2}: \text { Zn EDTA basal } \\
\left(40 \mathrm{~kg} \mathrm{ha}^{-1}\right)\end{array}$ & 0.35 & & & & & & & & \\
\hline $\begin{array}{l}\mathrm{T}_{3}: \mathrm{ZnSO}_{4} \text { foliar spray } \\
(0.5 \%)(30 \text { and } 45 \mathrm{DAT})\end{array}$ & 0.35 & 1.00 & & & & & & & \\
\hline $\begin{array}{l}\mathrm{T}_{4}: \text { Zn EDTA foliar spray } \\
(0.8 \%)(30 \text { and } 45 \text { DAT) }\end{array}$ & 0.35 & 0.86 & 0.86 & & & & & & \\
\hline $\mathrm{T}_{5}: \mathrm{T}_{1}+\mathrm{T}_{3}$ & 0.35 & 0.86 & 0.86 & 1.00 & & & & & \\
\hline $\mathrm{T}_{6}: \mathrm{T}_{2}+\mathrm{T}_{4}$ & 0.47 & 0.65 & 0.65 & 0.75 & 0.75 & & & & \\
\hline $\mathrm{T}_{7}: \mathrm{T}_{1}+\mathrm{T}_{4}$ & 0.41 & 0.69 & 0.69 & 0.69 & 0.69 & 0.81 & & & \\
\hline$T_{8}: T_{2}+T_{3}$ & 0.50 & 0.69 & 0.69 & 0.80 & 0.80 & 0.93 & 0.75 & & \\
\hline $\mathrm{T}_{9}:$ Control & 0.43 & 0.77 & 0.77 & 0.77 & 0.77 & 0.67 & 0.60 & 0.71 & \\
\hline
\end{tabular}

the leaf folder infested resistant and moderately resistant genotypes (Ptb 33, TKM6, LFR831311, ASD16, O. minuta and O. rhizomatis) of rice as compared to control healthy plants (Punithavalli et al., 2013). Thus, the present finding indicated that a sub-set of protein content indirectly influence insect resistance in rice plants. Plants respond to insect attack through a variety of defense mechanisms which may be either morphological adaptation (trichomes, pubesence, waxy cuticle), or elicitation of biochemical and molecular mode of defense systems (Belete, 2018). Induction of defense enzymes, bio-chemicals and resistant proteins by insect feeding has been reported in many insect-plant interactions (Radja Commare et al., 2002). Host plant 


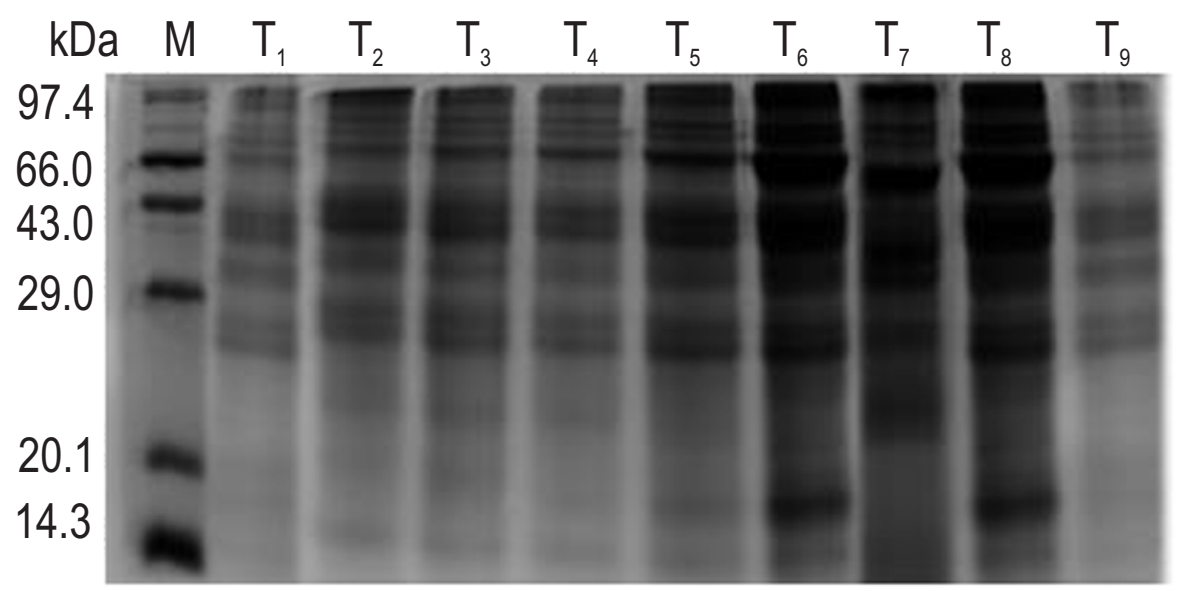

Fig. 1: SDS-PAGE soluble protein profile of various $\mathrm{Zn}$ treatments in rice $\mathrm{cv}$. TN 1 for elucidation of induced host plant resistance to WBPH. T1-T9: various $\mathrm{Zn}$ treatments (basal and/or foliar applications), M- Molecular weight marker.

resistance can be developed by appropriate breeding strategies. Besides, adequate level of resistance can be engineered genetically to build up endogenous defense biomolecules within the host plants to confer resistance to insects (Gatehouse, 2013). Many often, in absence of above inherent insect resistance mechanisms; induced resistance can be elicited in the host plants by use of chemical elicitors of secondary metabolites, potassic fertilizers or even chemical compounds containing silicon, zinc and ferrous. Zinc is needed for plant growth and resistance to biotic and abiotic stresses. Besides, zinc seems to be a major player in defense related response in plants (Gupta et al., 2012). Sufficient accumulation of zinc (either through uptake from soil or by foliar spray) followed by its cellular sequestration make the plants climatically more smart (abiotic stress tolerant), but the underlying mechanism is not explicitly delineated. It activates/stabilizes the activity of a number of metalloenzymes (Fones and Preston, 2012). Zn-SOD (super oxide dismutase) activity is commonly increased in herbivore/pathogen-challenged plants (Deepak et al., 2006). Besides, insect infestation in vogue elicits ZFN-transcriptional factor(s) synthesis (Lawrence et al., 2014) to impart host plant resistance.

Recent advances in microarray and proteomic approaches have revealed that a wide spectrum of plant resistance protiens is involved in plant defense against insects (Belete, 2018). Direct defenses, such as trypsin protein inhibitors in rice has anti-digestive or toxic effects on insect herbivores (Qi et al., 2018). In the present context, protein profile of various treatments exposed to different zinc fertilizer in pot culture experiment were analysed by SDS-PAGE method to ascertain whether zinc is responsible for production of any new defensive protein against WBPH or not. Altogether, nineteen polypeptide bands were revealed in response to extraneous application of zinc in form of basal and foliar application of $\mathrm{ZnSO}_{4}$ and $\mathrm{Zn} \mathrm{EDTA}$. Polypeptide bands i.e. B1 (97.4kDa), B2 (90kDa), B4 (78 kDa), B8
$(40.2 \mathrm{kDa})$ and $\mathrm{B} 13(27.3 \mathrm{kDa})$ in the zymogram are monomorphic over all the treatments and control indicating their expression independent of the zinc application (Table 2 and Fig. 1). It was observed that polypeptide bands of $29.0 \mathrm{kDa}, 35.0 \mathrm{kDa}, 56.8 \mathrm{kDa}$ and $85.5 \mathrm{kDa}$ were absent in basal application of $\mathrm{ZnSO}_{4}$, but induced in all treatments and even in control. In contrast, $33.0 \mathrm{kDa}$ and $25.1 \mathrm{kDa}$ polypeptides were induced by basal application of $\mathrm{ZnSO}_{4}$, but down regulated in all treatments including control. Zinc uptake in case of basal application is determined by presence of $\mathrm{Zn}$-transporter genes in root cells followed by transport to stem and foliage, while foliar application can bypass such genetic system and avail zinc directly to the enzymes required for plant growth and metabolism (Zhao et al., 2014). Basal application of Zn EDTA and also foliar application of $\mathrm{ZnSO}_{4}$ alone produced a polypeptide band of $20.1 \mathrm{kDa}$.

Two polypeptide bands viz., $37.0 \mathrm{kDa}$ and $66 \mathrm{kDa}$ were induced in $\mathrm{ZnSO}_{4}$ basal, but not expressed in control as well as in response to its foliar spray alone or its additional application as foliar spray. Even these two polypeptide bands were also not expressed in Zn-EDTA basal or foliar spray alone, but induced by combination of basal + foliar spray of $Z n-E D T A$ as well as combination of basal $\mathrm{ZnSO}_{4}+$ foliar $\mathrm{Zn}$ EDTA or vice versa. The low molecular weight proteins ranging from 14.3-25.1 kDa were clearly absent in the control, but zinc application in form of above sources as basal or foliar treatment elicited biosynthesis of new polypeptide bands. For instance, a polypeptide band ( $14.3 \mathrm{kDa})$ was noticed in all the zinc treatments except $\mathrm{ZnSO}_{4}$ basal. Besides, foliar spray of $\mathrm{Zn}$-EDTA in combination with basal application of either $\mathrm{ZnSO}_{4}$ or $\mathrm{Zn}$-EDTA induced new polypeptide band at $23.6 \mathrm{kDa}$. In the present investigation, elucidation of the induced polypeptide bands revealed in response to various treatments of zinc-application may throw light for better understanding about the biochemical basis of induced host plant 


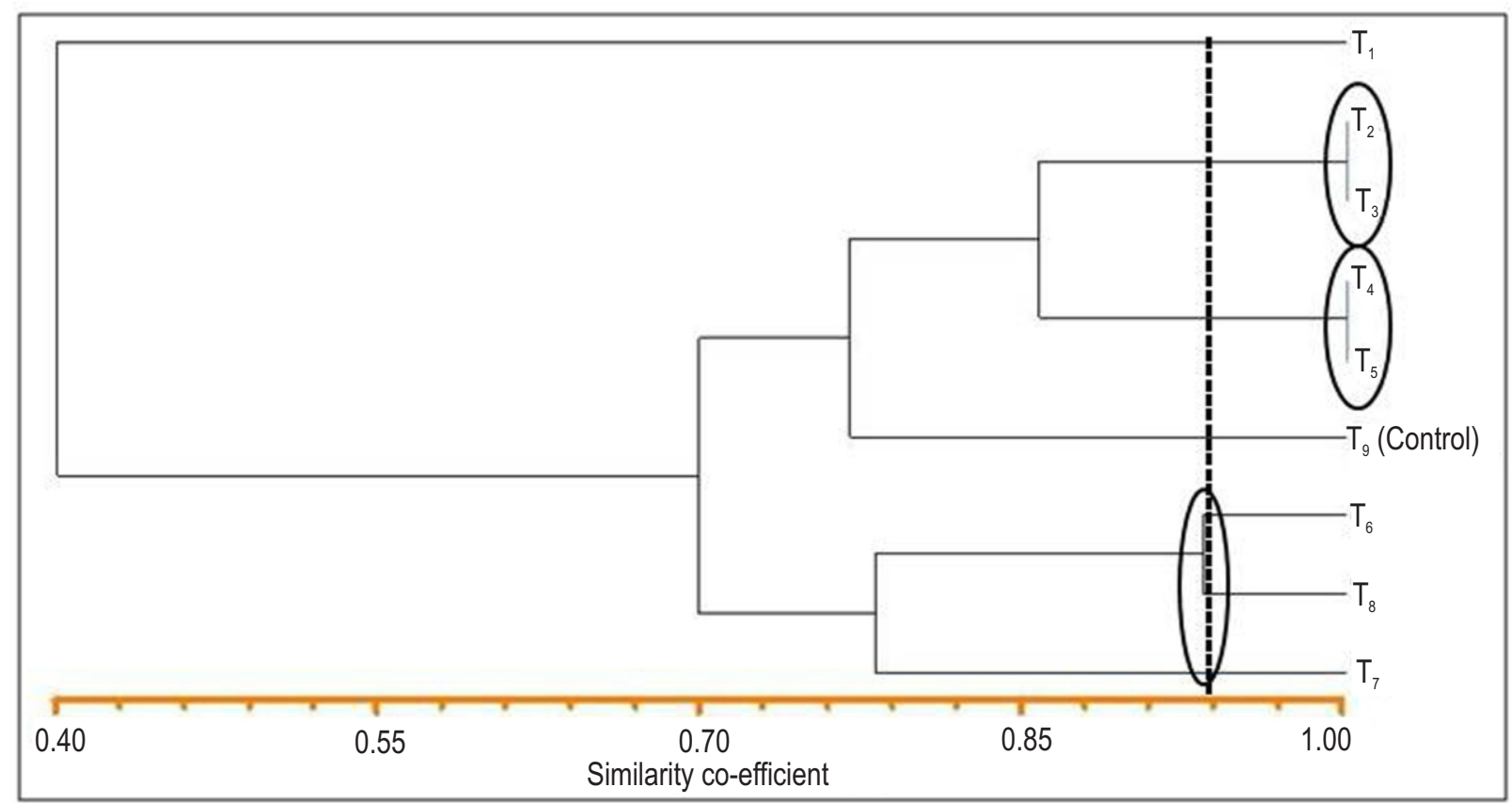

Fig. 2: Dendrogram depicting inter-relationship among various $\mathrm{Zn}$ treatments for induced resistance to WBPH in rice.

resistance to WBPH. Sinha et al. (2005) revealed overexpression of high molecular weight protein $(>97 \mathrm{kD})$ and a specific $38 \mathrm{kD}$ polypeptide band in leaf folder infested resistant parent as well as resistant RILs derived from a cross IR 36 (susceptible) x TNAULFR 831311 (Resistant) in rice. Thus, the induced polypeptide bands identified in the present investigation may serve as biochemical marker for WBPH resistance in rice.

WBPH is a dreadful sucking insect of rice and it usually attacks at culm base of rice plant at tillering and flowering stage causing drastic reduction in crop growth and seed yield (CRIDA,2019). Zinc application either as basal and/or foliar application reduced the population build up of WBPH ranging from 31.40 to 53.60 insects/hill as against control (79.20 insects/hill). Combination treatment of basal and foliar application of zinc formulation in the form of Zn EDTA $\left(T_{6}: T_{2}+T_{4}\right)$ resulted maximum dividend followed by $T_{7}\left(T_{1}+T_{4}\right)$ and $T_{8}\left(T_{2}+T_{3}\right)$ in term of decrease in WBPH population. In this context, it is worth to note that the most responsive zinc combination treatment $\left(T_{6}\right)$ elicited highest number (15) of polypeptide bands against ten normal protein bands in the control. Expression of five new polypeptide bands at 66.0, 37.0, 23.6, 15.8 and $14.3 \mathrm{kDa}$ induced by $\mathrm{T}_{6}$ can be considered as biochemical basis of induced resistance in rice against WBPH. Among these, 66.0, 37.0, 23.6 and $14.3 \mathrm{kDa}$ protein bands were induced by $T_{7}$ and $66.0,37.0,15.8$ and 14.3 $\mathrm{kDa}$ protein bands induced by $T_{8}$, were common to that of $T_{6}$, which were new types and not expressed in control treatment. Further, the soluble protein profiling study revealed that $66.0 \mathrm{kDa}$, $37.0 \mathrm{kDa}$ and $14.3 \mathrm{kDa}$ polypeptide bands were significantly induced and commonly shared in $\mathrm{T}_{6}, \mathrm{~T}_{7}$ and $\mathrm{T}_{8}$ that recorded lower
WBPH population. However, 23.6 kDa polypeptide band induced only in $T_{6}$ and $T_{7}$ seems to have greater role in manifestation of induced resistance to WBPH in rice. Induction of a defense related protein $(53 \mathrm{kDa})$, due to leaf folder infestation in resistant and moderately resistant rice varieties have been reported by Das et al. (1999). Similarly, Sinha et al. (2005) and Punithavalli et al. (2013) have also noticed enhanced expression of a high molecular weight $(>97 \mathrm{kDa}$ ) protein in all the genotypes but there was an increased induction of a $38 \mathrm{kDa}$ protein in leaf folder infested resistant rice genotypes, which was absent in uninfested plants. They reported these as a defense related proteins. Defence related proteins encoded by $R$ genes play critical roles in plant resistance to insects and pathogens (Dodds and Rathjen, 2010). More than $25 \mathrm{R}$ genes related to rice defense against $\mathrm{BPH}$ have been found (Cheng etal., 2013, Zhao et al., 2016).

A novel protein encoded by Bph 32 gene that offers resistance to BPH in rice has been identified (Ren et al., 2016). Therefore, the present finding lies in conformity with the finding of above authors. Further, clustering pattern (dendrogram) (Fig. 2) based on pair-wise similarity coefficient values (Table 3 ) revealed that $T_{1}, T_{9}$ (Control), $T_{6}, T_{7}$ and $T_{8}$ formed single treatment cluster while, both $T_{2}$ and $T_{3}$ together and also $T_{4}$ and $T_{5}$ combinedly formed separate clusters at $100 \%$ phenon level. Had there been fine tuning of the protein profiling, $T_{2}$ and $T_{3}$ might be separated and this difference could have been interpreted in terms of per cent damage difference between $T_{2}$ and $T_{3}$. Similarly, $T_{4}$ and $T_{5}$ could have been differentiated as difference between these was revealed in field and pot culture experiment. However, the difference between $T_{4}$ and $T_{5}$ was not so much vigilant as 
compared to their effect with either of $T_{6}, T_{7}$ or $T_{8}$, which revealed higher induction of host plant resistance to WBPH. Thus, plants respond to physical and chemical changes associated with insect feeding which in turn influences on the degree of damage by WBPH infestation. In the present study, low pest population buildup consequent with repression of few specific poypeptides and/or elicitation of new polypeptides induced in protein profile of WBPH-challenged rice plants following $\mathrm{Zn}$ application clearly indicates $\mathrm{Zn}$-induced host plant resistance to the pest.

\section{Acknowledgements}

The financial assistance provided by the Department of Science and Technology (DST), Govt. of India, New Delhi for the research work in terms of INSPIRE Fellowship to the first author is highly acknowledged. Further, Laboratory facilities provided by the Department of Agricultural Biotechnology, College of Agriculture, OUAT, Bhubaneswar is gratefully acknowledged.

\section{Add-on Information}

Authors' contribution: S. Tripathy: Contribution: Carried out the experiment and recorded data; L. K. Rath: Conceptualized and designed the experiment; S. K. Tripathy: Carried out data analysis and wrote the paper.

Research content: The research contents is original and has not been published elsewhere

Ethical approval: NotApplicable.

Conflict of interest: The author declares that there is no conflict of interest.

\section{Data from other sources: NotApplicable}

Consent to publish: All authors agree to publish the paper in Journal of Environmental Biology.

\section{References}

Andreini, C., I. Bertini and A. Rosato: Metalloproteomes: A bioinformatic approach. Acc. Chem. Res., 42, 1471-1479 (2009).

Beck, D. L., G.M. Dunn, D.O. Routley and J.S. Bowman: Biochemical basis of resistance in corn to the corn leaf aphid. Crop Sci., 23, 995-998 (1983).

Belete, T.: Defense mechanisms of plants to insect pests: From morphological to biochemical approach. Tren. Techni. Sci. Res., 2, 30-37(2018).

Cabot, C., S. Martos, M. Lugany, B. Gallego, R. Tolrà and C. Poschenrieder: A role for zinc in plant defense against pathogens and herbivores. Fron. Plant Sci., 10, 1171(2019).

Chandramani, P., R. Rajendran, C. Muthiah and C. Chinniah: Organic source induced silica on leaf folder, stem borer and gall midged population and rice yield. J. Biopesti., 3, 423-427(2010).

Chang, R.L., R.J. Arnold and X.D. Zhou: Association between enzyme activity levels in Eucalyptus clones and their susceptibility to the gall wasp, Leptocybe invasa, in South China. J. Tropi. Fore. Sci.,

\section{4, 256-264 (2012).}

Cheng, X.Y., L.L. Zhu and G.C. He: Towards understanding of molecular interactions between rice and the brown planthopper. Molecular Plant, 6, 621-634 (2013).

Das, A., S. Balasaraswathi, K. Sadasivam and S. Palaniswamy: Biochemical variations between leaf folder (Cnaphalocrosis medinalis Gunee) resistant and susceptible rice (Oryza sativa L.) varieties in healthy and infested plants. Indian J. Agricul. Biochem., 12, 1-4 (1999).

Dash, D. and P.R. Mishra: Influence of rice varieties and graded levels of plant nutrients on the effectiveness of insecticide against white backed plant hoppers (WBPH), Sogatella furcifera (Horvath). J. Entomol. Res., 33, 105-108 (2009).

Dash, D., B. Senapati and H.P. Patnaik: Influence of rice varieties and plant nutrients on the incidence of yellow stem borer, Scirpophaga incertulas (Walker) under protected condition. Indian J. Entomol., 73, 196-200 (2011)

Dash, D., L.K. Rath and B.K. Mishra: Studied on nutrient status in rice foliage and its relationship with leaf folder and brown plant hopper incidence. Indian J. Plant Prote., 35, 243-247(2007).

Deepak, S. A., H. Ishii and P. Park: Acibenzolar-S-methyl primes cell wall strengthening genes and reactive oxygen species forming/scavenging enzymes in cucumber after fungal pathogen attack. Physiol. Molec. Plant Pathol., 69, 52-61 (2006).

Dodds, P.N. and J.P. Rathjen: Plant immunity: Towards an integrated view of plant-pathogen interactions. Natu. Revi. Gene., 11, 539$548(2010)$.

Duncan, D.B.: Multiple range and multiple F-tests. Biometrics, 11, 1- 42 (1955).

Edwards, P.J. and S.D. Wratten: Wound induced defences in plant and their consequences for patterns of insect grazing. Oecologia, 59, 88-93 (1983)

Fones, H.N. and G.M. Preston: Reactive oxygen and oxidative stress tolerance in plant pathogenic Pseudomonas. FEMS Microbiol. Lett., 327, 1-8 (2012).

Gatehouse, J.A.: Genetic engineering of crops for insect resistance. In: Sustainable Food Production. (Eds.: P. Christou, R. Savin, B.A. Costa-Pierce, I. Misztal and C.B.A. Whitelaw). Springer, New York, (2013). doi: https://doi.org/10.1007/978-1-4614-5797-8_239

Gupta, S.K., A.K. Rai, S.S. Kanwar and T.R. Sharma: Comparative analysis of zinc finger proteins involved in plant disease resistance. PLoS ONE, 7, e42578 (2012). doi: 10.1371/journal. pone. 0042578

Heinrichs, E.A., F.G. Medrana and H.R. Rapusas: Genetic evaluation for insect resistance in rice. Int. Rice Res. Institute, Los Banos, Philippines, pp. 356 (1985).

Hori, K. and R. Atalay: Biochemical changes in the tissue of chinese cabbage injured by the bug lygus disponsi. Appl. Entomol. Zool., 15, 234-241(1980).

Jaccard, P.: Nouvelles recherches Sur la distribution florale. Bull. Soc. Vaud Sci. Natio., 44, 223-270(1908).

Kaur, R., A.K. Gupta and G.K. Taggar: Zinc as an important factor determining resistance against Helicoverpa armigera herbivory in pigeon pea (Cajanus cajan L.). Curr. Sci., 107, 1871(2014).

Khederi, S. J., M. Khanjani, M. Gholami, O. Panzarino and E. de Lillo: Influence of the erineum strain of Colomerus vitis (Acari: Eriophyidae) on grape (Vitis vinifera) defense mechanisms. Exp. Appli. Acarol., 75, 1-24 (2018).

Krishnaiah, N.V., V. Jhansilakshmi, I.C. Pasalu, G.R Katti and C. Padmavathi: Insecticides in Rice IPM: past, present and future. Directorate of Rice Research, Hyderabad, pp. 146 (2008).

Lagrimini, L.M. and S. Rothstein: Tissue specificity of tobacco peroxidase isozymes and their induction by wounding and tobacco 
mosaic virus infection. Plant Physiol., 84, 438-442 (1987).

Lawrence, S.D., N.G. Novak, R.W. Jones, R.R. Farar and M.B. Blackburn: Herbivory responsive $\mathrm{C} 2 \mathrm{H} 2$ zinc finger transcription factor proteins StZFP2 from potato. Plant Physiol. Biochem., 80, 226-233 (2014).

Lowry, D.H., N.J. Rosebrough, A.L. Farr and J.L. Randall: Protein measurement with the Folin phenol reagent. J. Biol. Chemi., 193, 265-275 (1951).

Madhuri, G., P.C. Dash and P. Pruthvi : Impact of different graded levels of fertilizers on the incidence of yellow stem borer Scirpophaga incertulas (Walker), leaf folder Cnaphalocrocis medinalis (Guenee) and whorl maggot, Hydrellia philippina (Ferino) in paddy. Int. J. Curr. Microbiol. Appli. Sci., 6, 793-803 (2017).

Marreiro, D.D., K.J. Cruz, J.B. Morais, J.B. Beserra, J.S. Severo and A.R. de Oliveira: Zinc and oxidative stress: Current mechanisms. Antioxidants (Basel), 6, 24 (2017).

Punithavalli, M., N.M. Muthukrishnan and M. Balaji Rajkumar: Defensive responses of rice genotypes for resistance against rice leaf folder, Cnaphalocrocis medinalis. Rice Sci., 20, 363-370 (2013).

Qi, J., S. Malook, G. Shen, L. Gao, C. Zhang, J. Li, J. Zhang, L. Wang and $\mathrm{J}$. Wu: Current understanding of maize and rice defense against insectherbivores. Plant Divers., 40, 189-195 (2018).

Radja Commare, R., R. Nandakumar, A. Kandan, S. Suresh, M. Bharathi, T. Raguchander and R. Samiyappan: Pseudomonas fluorescences based bio-formulation for the management of sheath blight and leaf folder insect in rice. Crop Prote., 21, 671-677 (2002).

Raghumoorthy, K.N. and K. Gunathilagaraj: Field incidence of and host resistance to Angoumois grain moth (AGM). Int. Rice Res. Newsletter, 13, 12 (1988).

Rath, L.K.: Micronutrient induced antibiosis in rice against brown plant hopper, Nilaparvata lugens (Stal). J. Plant Prote. Environ., 3, 29-33 (2006).

Rath, L.K.: Influence of certain micronutrients on the growth and development of white backed plant hopper, Sogatella furcifera
(Horvath) infesting rice. J. Plant Prote. Environ., 1, 19-23 (2004).

Ren, J., F. Gao, X. Wu, X. Lu, L. Zeng, J. Lv, X. Su, H. Luo and G. Ren: Bph32, a novel gene encoding an unknown SCR domaincontaining protein, confers resistance against the brown planthopper in rice. Scientific Reports, 6, Article No- 37645 (2016).

Satpathy, S., B.S. Gotyal and V. Ramesh Babu: Role of novel insecticides in crop protection and their selectivity to natural enemies: A review. J. Environ. Biol., 41, 149-160 (2020).

Sidhu, G.S.: Need for varieties resistant to white backed plant hopper in Punjab. Int. Rice Res. Newsletter, 14, 6-7(1979).

Sinha, S., R. Balasaraswathi, K. Selvaraju and P. Shanmugasundaram: Molecular and biochemical markers associated with leaf folder (Cnaphalocrocis medinalis G.) resistance in rice (Oryza sativa L.). Indian J. Bioche. Biophy., 42, 228-232 (2005).

Sogawa, K., G. Liu and Q. Qiang: Prevalence of white backed plant hoppers in Chinese hybrid rice and white backed plant hopper resistance in Chinese japonica rice. In: Planthoppers: New Threats to the Sustainability of Intensive Rice Production Systems in Asia. (Eds.: K.I. Heong and B. Hardy), Los Banos (Philippines), pp. 257280 (2009)

Sokal, R.R. and C.D. Michener: A statistical method for evaluating systematic relationships. University Kansas Science Bulletin, 28, 1409-1438 (1958).

Zhai, H.W., Y.F. Zhao, X.W. Gao and M.X. Wu: Efficacy of Empedobacter brevis in controlling rice stem borer. Bio. Disas. Sci., 36, 291-294 (2013).

Zhao, A.Q., X.H. Tian, Y.X. Cao, X.C. Lu and T. Liu: Comparison of soil and foliar zinc application for enhancing grain zinc content of wheat when grown on potentially zinc-deficient calcareous soils. J. Sci. FoodAgricul., 94, 2016-2022 (2014).

Zhao, Y., J. Huang and Z.Z. Wang: Allelic diversity in an NLR gene BPH9 enables rice to combat planthopper variation. In: Proceedings of National Academy of Sciences, USA, 113, 12850-12855 (2016). 